\title{
Water Absorption of Hemp Fibre Nonwovens Modified with Metal and Metal Oxide Nanoparticles
}

\author{
Uljana Iljina ${ }^{1}$, Ilze Baltina ${ }^{2}$, Andrejs Lusis ${ }^{3}$ \\ 1,2 Institute of Design Technologies, Faculty of Materials Science and Applied Chemistry, Riga Technical University, \\ ${ }^{3}$ Institute of Solid State Physics, University of Latvia
}

\begin{abstract}
In this paper changes of ability of hemp fibre nonwovens to absorb water after deposition of metal and metal oxide nanoparticles were investigated. Moisture content of samples after storage in different climatic conditions was determined using thermogravimetric method. The obtained results were compared with the results of previous research based on investigation of water absorption of metalized woven fabric of bast fibre.

Analysis of measurements showed that nonwoven samples with surface treated in plasma attract water slightly better than sample with untreated surface; this was more pronounced in woven fabric samples. In turn, metal coatings reduced water sorption. Unlike woven fabric samples, nonwoven samples attract similar water quantity irrespectively of surface modification. It can be concluded that metallization of hemp fibre nonwovens retain hygroscopic properties of these textile materials. Therefore, moisture content also needs to be controlled in nonwovens with metal and metal oxide nanoparticle coatings.
\end{abstract}

Keywords - Hemp fibres, nonwovens, metal coatings, thermogravimetry, water absorption.

\section{INTRODUCTION}

Metallization of textile materials is widely used in the world. It allows to change properties of textile materials, thus, also changing their applications. Surface coating with metal and metal oxide nanoparticles makes it possible to develop new light weight, flexible products with metalic characteristics such as conductivity, protection against radiation, antibacterial properties, etc., (1)-(5).

Synthetic textile materials are often coated with metals because of their regular structure and hydrophobic properties. However, these materials tend to be replaced by natural, degradable and renewable materials. When metallizing textile materials made from natural fibres it is important to pay attention to their hygroscopic properties as well as on the ability of nanoparticle coating to promote or impede the attraction of moisture. Moisture absorption in natural fibres leads to modification of their physical and chemical properties. Additionally, water is electrically conductive and water absorption can affect electrical properties of textile materials after metallization. Such effects lead to a strong dependence of textile materials on ambient conditions; this is not desirable for technical textiles (6)-(8).

The goal of this work was to investigate changes of the ability of hemp fibre nonwovens to absorb water after deposition of metals and metal oxide nanoparticles. The obtained results were compared to the results of previous research based on metalized bast fibre woven fabrics. In the previous research the changes in ability of metalized bast fibre woven fabrics to absorb water were investigated (13). Obtained characteristics of modified woven fabrics were shown not to be particularly well suited substrate material for deposition. The unevenness of density of woven fabric and a large quantity of through pores were the reason for this. Therefore, in the further study it was decided to use nonwoven as a substrate instead of woven fabric. Nonwowen is even at a sufficient density and is not characterized by through pores (9).

\section{MATERIALS AND METHODS}

In the experimental part of the work the following tasks were carried out:

- Thin metal coatings and metal oxide coatings were applied;

- Moisture content was analysed by using thermogravimetric method.

Hemp fibre nonwovens produced from Bialobrzeskie type hemp fibre grown in Latvia using a parallel-laid carding method and hydroentanglement method were investigated (10).

Nonwovens were coated with $\mathrm{Ni}, \mathrm{Cu}, \mathrm{Al}, \mathrm{NiO}$ and $\mathrm{CuO}$ coatings from one and from both sides. Thin metal and metal oxide coatings were applied using direct currect (DC) magnetron metal coating and reactive oxide coating methods. For the first sample surface etching was performed and no coating was applied so that changes of the properties of the nonwoven material could be evaluated after cleaning the surface (11), (12). Technical data of thin film deposition process is given in Table I. Previously studied samples of woven fabric were modified using the same method and the same coating materials. Technical data for thin film deposition is displayed in (13).

Thermogravimetric method was used to investigate the moisture content of hemp fibre nonwovens. Thermogravimetric method is based on continuous recording of mass changes of a sample of the material as a function of a combination of temperature and time. When samples are heated water and other substances evaporate from the samples. Chemical reactions and dilapidation can take place in the sample at $70{ }^{\circ} \mathrm{C}$ temperature. This method was used to determine of water absorption characteristics of samples with and without metal and metal oxide coatings. Thermogravimetric analysis was performed for samples held in normal climatic conditions $(65 \pm 5 \%$ relative humidity of air, $20 \pm 2{ }^{\circ} \mathrm{C}$ temperature) and samples held in environment with 95-98\% relative humidity. Differential thermogravimetric analyser DTG- 60 was used. The experiment 
was carried out in argon gas atmosphere. Temperature amplitude was $35-230^{\circ} \mathrm{C}$ and it was increased linearly with $10^{\circ} \mathrm{C} \cdot \mathrm{min}^{-1}$. During the experiment mass loss (in $\mathrm{mg}$ ) was measured every second. The measurement results of $\mathrm{TG}$ analysis were displayed linearly in graph by software $T A-60 \mathrm{WS}$ $(13)-(15)$.

\section{RESULTS AND DISCUSSION}

Here thermogravimetry measurement data is analysed and the results of thermogravimetric analysis of previously researched woven fabric and nonwoven samples are compared (13).

TABLE I

TECHNICAL DATA FOR DEPOSITION OF THIN COATINGS

\begin{tabular}{|c|c|c|c|c|c|c|c|c|c|}
\hline \multirow{2}{*}{ 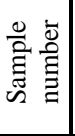 } & \multirow{2}{*}{ 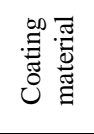 } & \multirow{2}{*}{ 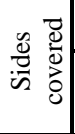 } & \multicolumn{2}{|c|}{ Etching } & \multicolumn{5}{|c|}{ Applying of thin coatings } \\
\hline & & & $\begin{array}{l}\text { Etching time, } \\
\text { min }\end{array}$ & $\begin{array}{l}\text { Gas flow, } \\
\text { SCCM }\end{array}$ & $\begin{array}{l}\text { Current } \\
\text { mode }\end{array}$ & Power, W & $\begin{array}{c}\text { Gas flow, } \\
\text { SCCM }\end{array}$ & $\begin{array}{l}\text { Dissipation } \\
\text { time, min }\end{array}$ & $\begin{array}{l}\text { Thickness of the } \\
\text { applied coating, nm }\end{array}$ \\
\hline 1 & Etched & I & 3 & 7.5 & - & - & - & - & - \\
\hline 2 & $\mathrm{Ni}$ & I & 3 & 7.5 & $\mathrm{RF}$ & 500 & $\mathrm{Ar}=6.5$ & 20 & 370 \\
\hline 3 & $\mathrm{Cu}$ & I & 25 & 7.5 & RF & 350 & $\mathrm{Ar}=7.5$ & 30 & 609 \\
\hline 4 & $\mathrm{Al}$ & I & 3 & 7.5 & DC & 400 & $\mathrm{Ar}=5.5$ & 15 & 515 \\
\hline 5 & $\mathrm{NiO}$ & I & 3 & 7.5 & $\mathrm{RF}$ & 500 & $\begin{array}{c}\mathrm{Ar}=5.5 \\
\mathrm{O}_{2}=5.5\end{array}$ & 40 & 530 \\
\hline 6 & $\mathrm{CuO}$ & I & 5 & 7.5 & $\mathrm{RF}$ & 350 & $\begin{array}{c}\mathrm{Ar}= \\
10.5 ; \mathrm{O}_{2} \\
=2.6\end{array}$ & 15 & 514 \\
\hline \multirow{2}{*}{7} & \multirow{2}{*}{$\mathrm{Ni}$} & I & 3 & 7.5 & $\mathrm{RF}$ & 500 & $\mathrm{Ar}=6.5$ & 20 & 494 \\
\hline & & II & 3 & 7.5 & $\mathrm{RF}$ & 500 & $\mathrm{Ar}=6.5$ & 20 & 470 \\
\hline \multirow{2}{*}{8} & \multirow{2}{*}{$\mathrm{Cu}$} & $\mathrm{I}$ & 25 & 6.5 & $\mathrm{RF}$ & 300 & $\mathrm{Ar}=7.5$ & 12 & 726 \\
\hline & & II & 5 & 6.5 & $\mathrm{RF}$ & 300 & $\mathrm{Ar}=7.5$ & 12 & 980 \\
\hline \multirow{2}{*}{9} & \multirow{2}{*}{$\mathrm{Al}$} & I & 3 & 7.5 & DC & 400 & $\mathrm{Ar}=5.5$ & 15 & 625 \\
\hline & & II & 3 & 7.5 & DC & 400 & $\mathrm{Ar}=5.5$ & 15 & 714 \\
\hline \multirow{2}{*}{10} & \multirow{2}{*}{$\mathrm{NiO}$} & $\mathrm{I}$ & 3 & 7.5 & RF & 500 & $\begin{array}{l}\mathrm{Ar}=5.5 \\
\mathrm{O}_{2}=5.5\end{array}$ & 35 & 409 \\
\hline & & II & 3 & 7.5 & $\mathrm{RF}$ & 500 & $\begin{array}{l}\mathrm{Ar}=5.5 \\
\mathrm{O}_{2}=5.5\end{array}$ & 35 & 391 \\
\hline \multirow{2}{*}{11} & \multirow{2}{*}{$\mathrm{CuO}$} & I & 5 & 7.5 & $\mathrm{RF}$ & 350 & $\begin{array}{c}\mathrm{Ar}= \\
10.5 ; \mathrm{O}_{2} \\
=2.6\end{array}$ & 15 & 190 \\
\hline & & II & 5 & 7.5 & $\mathrm{RF}$ & 350 & $\begin{array}{c}\mathrm{Ar}= \\
10.5 ; \mathrm{O}_{2} \\
=2.6\end{array}$ & 15 & 330 \\
\hline
\end{tabular}
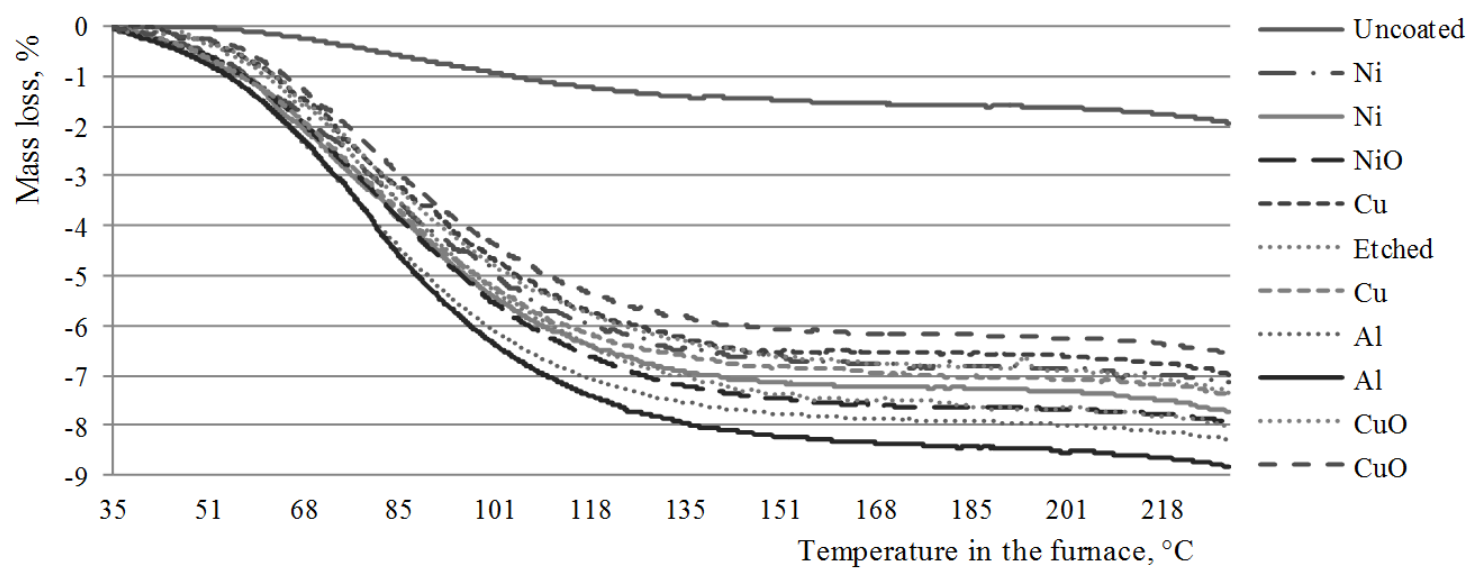

Fig. 1. Mass loss from woven fabric samples held in normal climatic conditions depending on temperature (13). 


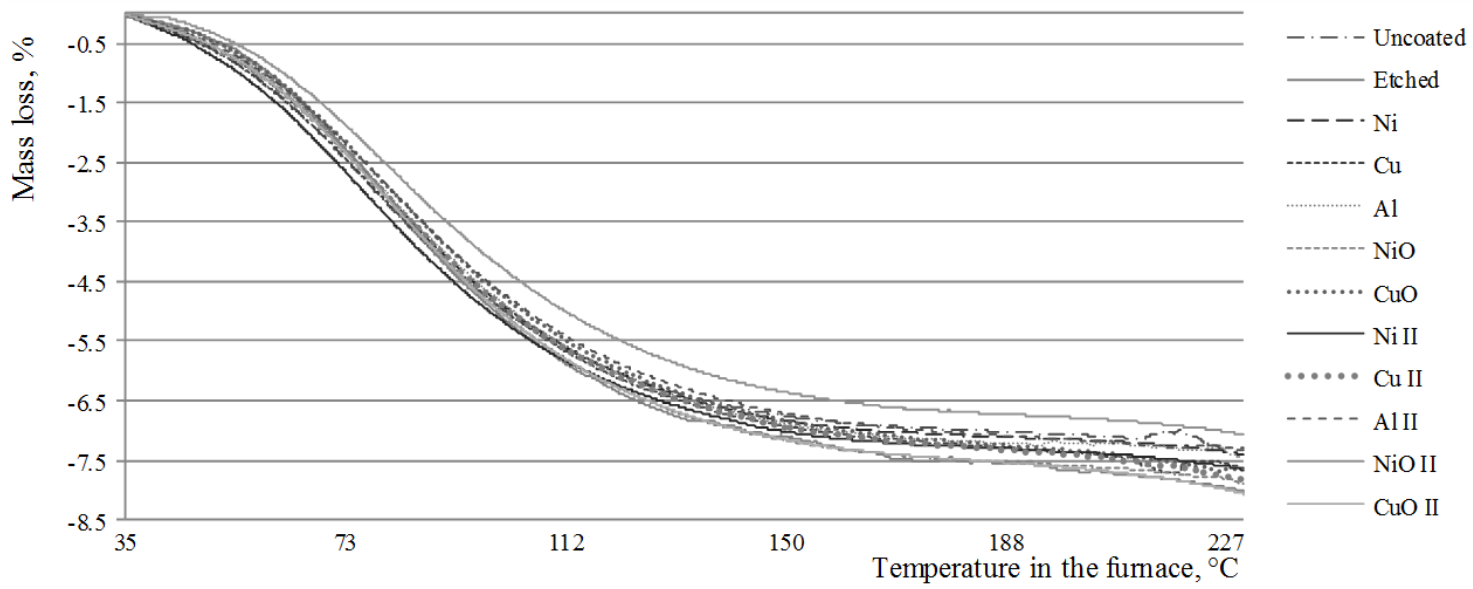

Fig. 2. Mass loss of nonwoven samples held in normal climatic conditions depending on temperature.
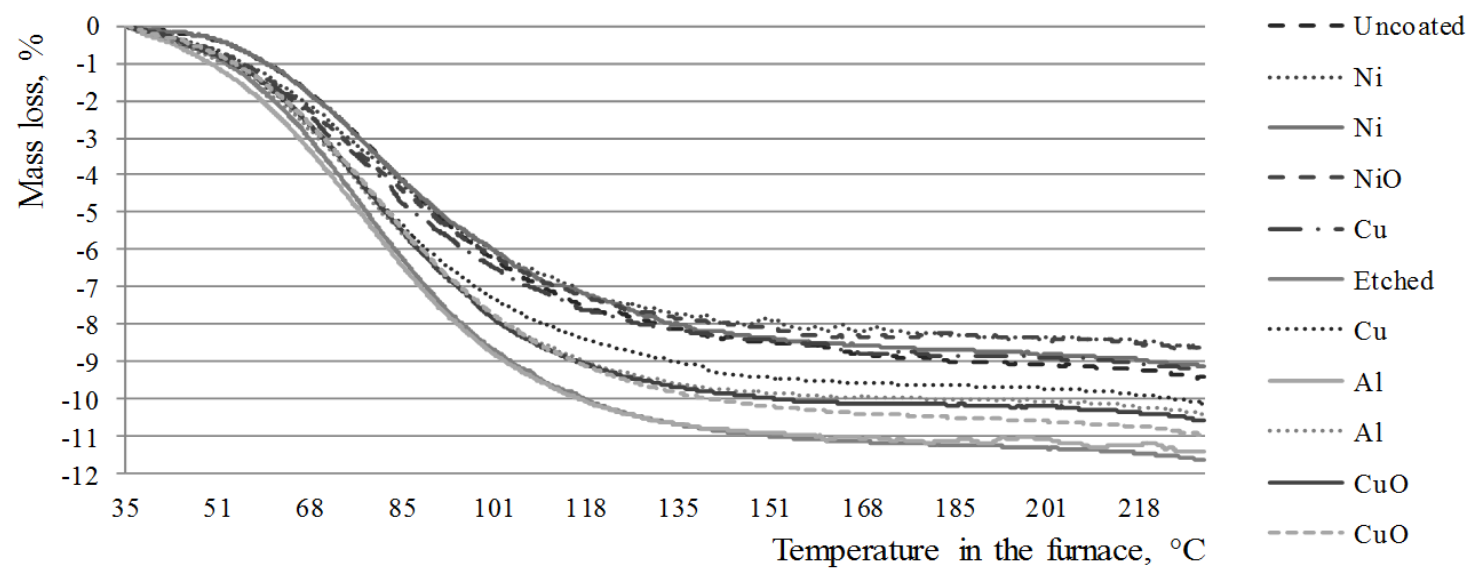

Fig. 3. Mass loss of moist woven fabric samples depending on temperature (13).

Thermogravimetry measurements for woven fabric samples held in normal climatic conditions are given in Fig. 1. Woven fabric samples, after holding them in normal climatic conditions, lose 6-9\% by weight. From these samples the sample with Al coating and with the second thickest coating $(970 \mathrm{~nm})$ had the greatest loss of weight $(8.8 \%)$. Also from these samples the sample with the third thickest coating of $\mathrm{CuO}$ $(730 \mathrm{~nm})$ had the smallest loss of weight $(6.6 \%)$. Therefore, it can be concluded that moisture absorption properties were not directly dependent on the thickness of the coating. The exception is the uncoated woven fabric sample that lost only $2 \%$ by weight. Cleaning and etching of the sample surface affects weight loss, because surface becomes active and attracts more moisture. It can also be concluded that etched woven fabric samples held in normal climatic conditions attracted water much better than the uncoated sample (13).

Thermogravimetry measurements for nonwoven samples held in normal climatic conditions are given in Fig. 2. Nonwoven samples lost 7-8 \% of their weight. All nonwoven samples have almost equal weight losses, showing that they are more uniform than woven fabric samples and attract a similar amount of water regardless of the surface modification. The sample with $\mathrm{NiO}$ coating on both sides had the smallest loss of weight $-7.1 \%$. The etched sample and sample with $\mathrm{CuO}$ coating on both sides had the greatest loss of weight $-8 \%$. Both of these samples are etched and this allows better water retention. Also one of them is covered with the thinnest layer of $\mathrm{CuO}$ nanoparticles compared to other coated samples, so it is able to absorb more water. 


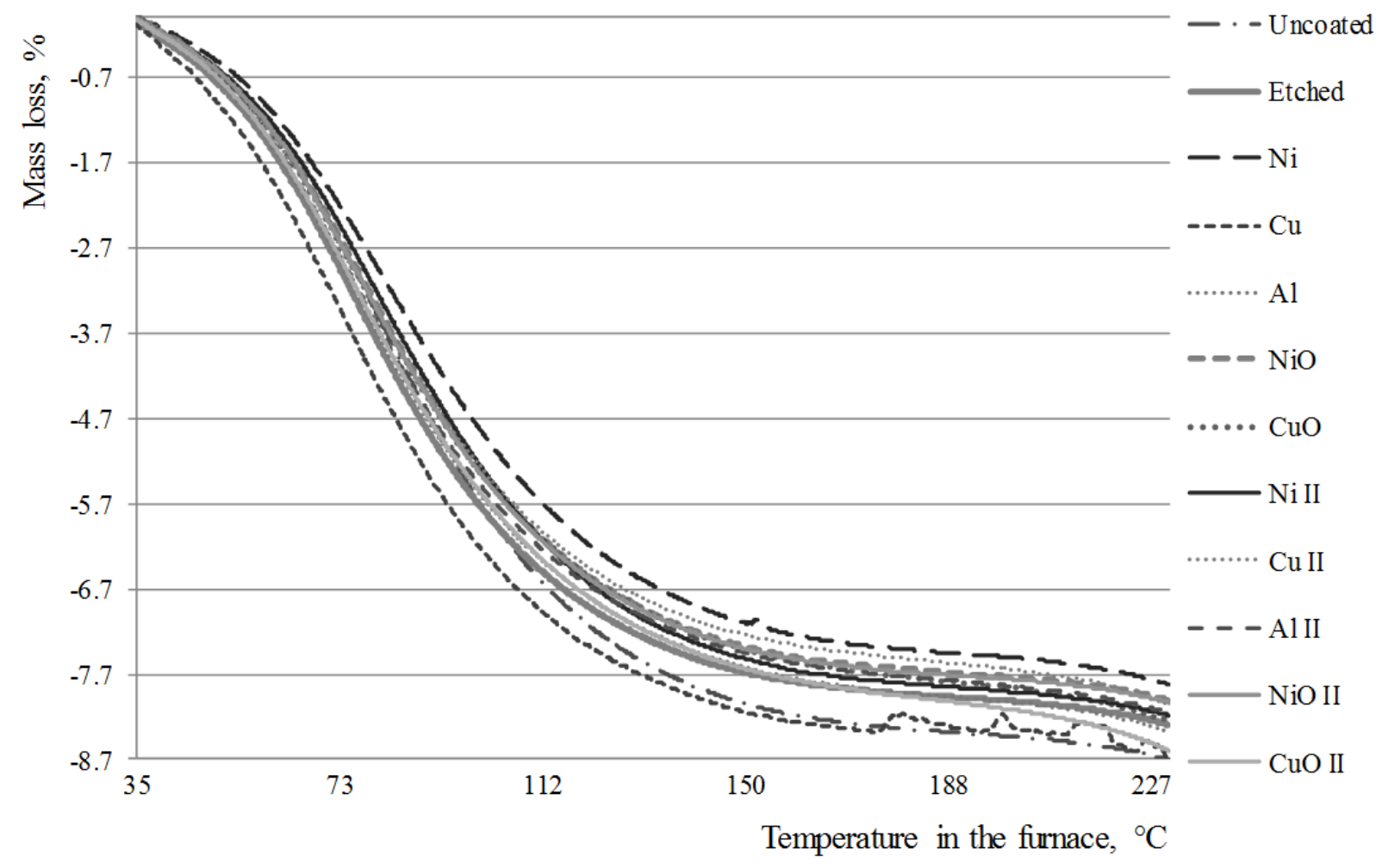

Fig. 4. Mass loss of moist nonwoven samples depending on temperature.

Mass loss of moist woven fabric samples under the influence of temperature is shown in Fig. 3. Moist woven fabric samples lose $8-12 \%$ of the original mass. Mass loss of uncoated moist woven fabric sample is similar to mass loss of other samples $9.4 \%$. Moist etched sample and sample with thinnest $\mathrm{Al}$ coating had the greatest loss of mass $-11.7 \%, 11.4 \%$. Their surface is the best for water attraction. Samples with $\mathrm{Ni}$ and $\mathrm{NiO}$ coatings on one side had the smallest loss of mass $-8.6 \%$ and $8.7 \%$. It can be concluded that the moist etched sample without coating attracts water much better than other samples, but the coating reduces water attraction (13).

Mass loss of moist nonwoven samples under influence of temperature is shown in Fig. 4. After holding in 95-98\% relative humidity the mass loss of nonwoven samples is $8-9 \%$. Again the data again shows that nonwoven samples have more uniform structure than woven fabric samples and attract water equally good. Sample with Ni coating had the smallest loss of mass $-7.8 \%$. Uncoated sample and sample coated with $\mathrm{Cu}$ nanoparticles that were etched for $25 \mathrm{~min}$ and $5 \mathrm{~min}$ had the biggest loss of mass $-8.7 \%$.

\section{CONCLUSION}

Changes in hemp fibre nonwovens ability to absorb water have been investigated after deposition of metal and their oxide nanoparticles. Samples with $\mathrm{Ni}, \mathrm{Cu}, \mathrm{Al}, \mathrm{NiO}$ and $\mathrm{CuO}$ coatings have been created and for one sample, only surface cleaning was performed. Water attraction properties have been determined for samples with/without surface modification, samples held in normal climatic conditions and in air with moisture content of 95-98\%. The obtained results were compared with the results of previous research based on investigation of water absorption of metalized bast fibre woven fabric. (13)

After performing the thermogravimetric analysis, it was concluded that:

- Unlike woven fabric samples, hold in normal climatic conditions, the etching process do not significantly affect the ability of nonwovens to absorb water, but it can be observed that the coatings slightly reduced it.

- Almost uniform weight loss of nonwoven samples shows that they are more even than previously studied woven fabric samples and attracts a similar amount of water regardless of the surface modification.

It can be concluded that metallization of hemp fibre nonwovens retains hygroscopic property of this textile materials independent of coating thickness. Therefore, moisture content must be controlled also in nonwovens with coating of metal and their oxide nanoparticles.

\section{REFERENCES}

1. Gorberg, B. L., Ivanov, A. A., Mamontov, O. V., Stegnin, V. A., Titov, V. A. Modification of Textile Materials by the Deposition of Nanocoatings by Magnetron Ion-Plasma Sputtering. Russian Journal of General Chemistry. vol. 83, no. 1, 2013, pp. 157-163. ISSN 1070-3632. http://dx.doi.org/10.1134/S1070363213010350

2. Deng, B., Wei, Q.F, Gao, W. Physical properties of Al-doped ZnO films deposited on nonwoven substrates by radio frequence magnetron sputtering. J. Coat. Technol. Res.. 5 (3), 2008, pp. 393-397. http://dx.doi.org/10.1007/s11998-008-9087-7

3. Ronghui G. A study of optimizing processes for metallized textile design application. The Hong Kong Polytechnic University, 2010.

4. Wang, Y. Y., Wei, Q. F., Shao, D. F., Cai, Y. B., Yu, L. Y. Optoelectrical properties of PET spunbonded nonwovens deposited with ITO thin films by RF sputter coating. Surface Engineering. Vol. 25, No. 7, 2009, pp. 531534. http://dx.doi.org/10.1179/174329408X315616 
5. Xu, Y., Wang, H.F., Wei, Q.F, Liu, H., Deng, B. Structures and properties of the polyester nonwovens coated with titanium dioxide by reactive sputtering. J. Coat. Technol. Res. 7 (5), 2010, pp. 637-642. http://dx.doi.org//10.1007/s11998-010-9243-8

6. Blackburn R.S. Biodegradable and sustainable fibres. Cambridge: Woodhead publishing in textiles, England, 2005. 464 pp. ISBN 9781855739161.

7. Kukle, S., Vihodceva, S. Application of Vacuum Evaporation to Obtain Natural Fiber Textile Products Ultra Thin Metallic Coatings. In: 41st International Symposium on Novelties in Textiles: Symposium Proceedings, Slovenia, L̦ubḷana, 27-29 May, 2010. Ljubljana: University of Ljubljana. Faculty of Natural Sciences and Engineering. Department of Textiles, 2010, pp. 413-419. ISBN 9789616045803.

8. Patra, J. K., Gouda, S. Application of nanotechnology in textile engineering: An overview. Journal of Engineering and Technology Research. Vol. 5(5), 2013, pp. 104-111. ISSN 2006-9790 http://dx.doi.org/10.5897/JETR2013.0309

9. Chapman, R. A. Applications of nonwovens in technical textiles. Cambridge, U.K.: Woodhead Publishing in association with the Textile Institute; Boca Raton, Fla.: CRC Press, 2010. 212 pp. ISBN 1613443838. http://dx.doi.org/10.1533/9781845699741

10. Iljina, U., Baltina, I., Russell, S. The Development of Hemp Fibre Nonwovens. Advanced Materials Research. Vol. 1117, 2015, pp. 227 230. http://dx.doi.org/10.4028/www.scientific.net/AMR.1117.227

11. Kestell, A. E., DeLorey, G. T. Nanoparticles: Properties, Classification, Characterization, and Fabrication. Nova Science Publishers, Inc., 2010.

12. Xia, Y., Xiong, Y., Lim, B., Skrabalak, S. E. Shape-Controlled Synthesis of Metal Nanocrystals: Simple Chemistry Meets Complex Physics? Angew. Chem. Int. Ed. 48, 2009, pp. 60-103. http://dx.doi.org/10.1002/anie.200802248

13. Sidorovica, U., Baltina, I., Lūsis, A., Zandersons, J. The Electrical Properties of Bast Fibre Fabrics Change after Nanoparticles of Metals and their Oxides are Applied. Material Science. Textile and Clothing Technology. Vol.8, 2013, pp. 54-59. ISSN 16913132. http://dx.doi.org/10.7250/mstct.2013.009

14. Gabbott, P. Principles and applications of thermal analysis// Blackwell Publishing Ltd, 2008. 459 pp.

15. Шаталова. Т.Б., Шляхтин О.А., Веряева Е. Методы термического анализа. Методическая разработка. Москва: Московский Государственный университет имени М. В. Ломоносова, 2011. / Satalova, T.B., Slahtin, O.A., Veraeva, E. Metodi termicheskogo analiza. Metodicheskaja razrabotka. - Maskva: Moskovskij Gosudarstvennij universitet im. M. V. Lomonosova, 2011.

Uḷjana Iḷjina, Ilze Baltiņa, Andrejs Lūsis. Kaṇepāju šķiedru neaustās drānas modificētas ar metālu un to oksīdu nanodaļiņām

Tekstilmateriālu metalizācija ir plaši izmantota to modifikācija, kas l̦auj mainīt tekstilmateriālu īpašības, izmainot to pielietojumu. Virsmas pārklāšana ar metāla un metāla oksīda nanodalininām l̦auj iegūt vieglus, lokanus materiālus ar metāliem raksturīgām īpašībām - elektrovadāmību, aizsardzību pret starojumu, ar antibakteriālām īpašībām, u.c. Parasti metāla pārklājumus uznes uz sintētiskiem tekstilmateriāliem to vienmērīgās struktūras dēḷ. Taču vērojama tendence šos sintētiskos materiālus aizstāt ar dabīgu, pārstrādājamu materiālu, kas dabā noārdās. Metalizējot tekstilmateriālus, kas izgatavoti no dabīgām šķiedrām, jāṇem vērā, ka šiem materiāliem piemīt higroskopiskas īpašības. Ūdenim piemīt elektrovadāmība un tas var ietekmēt metalizētu tekstilmateriālu elektriskās īpašības.

Eksperimentālā dạ̦ā pētīts kā mainās kaņepāju šķiedru neausto drānu spēja piesaistīt ūdeni pēc metālu un to oksīdu nanodalinu uznešanas. Iegūtie rezultāti salīdzināti ar metalizētu lūksnes šḳiedru auduma paraugu ūdens absorbcijas spējām. Mitruma saturs pētāmos paraugos noteikts, izmantojot termogravimetrijas metodi. Ūdens saturs pētīts tekstilmateriāliem pēc to izturēšanas dažādos klimatiskos apstākḷos - normālos un 95$98 \%$ relatīvajā mitrumā - analizējot paraugu masas zudumus atkarībā no karsēšanas temperatūras.

Veiktie pētījumi parāda, ka kodināšanas jeb virsmas attīrī̌sanas process tik būtiski neietekmē neausto drānu spēju piesaistît ūdeni, kā tas ietekmē auduma paraugu spēju piesaistīt ūdeni. Taču metālu un metāla oksīdu nanodaļiņu uznešana šo spēju pasliktina. Paraugu salīdzinoši vienādie masas zudumi parāda, ka neausto drānu paraugi ir vienmērīgāki, nekā iepriekš pētītie auduma paraugi, un piesaista līdzīgu ūdens daudzumu, neatkarīgi no virsmas modifikācijas. Var secināt, ka lūksnes šķiedru tektilmateriālu metalizācija vāji ietekmē šo materiālu higroskopiskās īpašības. Tādēḷ mitruma saturs šādos metalizētos materiālos ir jākontrolē.

Ульяна Ильина, Илзе Балтыня, Андрей Лусис. Нетканые материалы из конопляных волокон, модифицированные металлическими и металлооксидными наночастицами

Металлизация текстильных материалов является широко распространенным видом модификации, который позволяет изменить свойства текстильных материалов, таким образом изменяя сферу их применения. Покрытие поверхности металлическими и 
металооксидыми наночастицами позволяет получить лёгкие, гибкие материалы со свойствами, характерными для металла электропроводность, защита от излучения, антибактериальные свойства и др. Обычно металлические покрытия наносят на синтетические текстильные материалы по причине однородности структуры. Однако наблюдается тенденция к замене синтетических субстратов на натуральные материалы, подлежащие переработке и биологическому разложению. Металлизируя текстильные материалы из натуральных волокон, следует учитывать, что эти материалы обладают гигроскопическими свойствами. Воде присуща электропроводность, которая может повлиять на электрические свойства металлизированного текстиля.

В экспериментальной части исследованы изменения способности нетканого материала из конопляных волокон впитывать влагу после нанесения металлических и металлооксидных наночастиц, также проведено сравнение полученных результатов с результатами свойств поглощения влаги ранее исследованных образцов из лубяной ткани. Содержание влаги в исследуемом материале определяется методом термогравиметрии. Исследована потеря веса образцов в зависимости от температуры, после выдерживания в различных климатических условиях -нормальных климатических условиях и при влажности воздуха 95-98\%.

Проведенные исследования показывают, что процесс очищения поверхности в плазме несущественно влияет на способность нетканого материала впитывать влагу, в отличие от влияния на способность лубяной ткани поглощать влагу, в то время как нанесение металлических и металлооксидных наночастиц ухудшает эту способность. Относительно схожие потери массы нетканых образцов показывают, что образцы из нетканого материала равномернее образцов из лубяной ткани и впитывают схожее количество влаги, независимо от модификации поверхности. Можно сделать вывод, что металлизация текстильных материалов из лубяных волокон сохраняет гигроскопичность этих текстильных материалов. Поэтому содержание влаги в металлизированных текстильных материалах должно контролироваться. 